\title{
TGF-Beta Receptor Type-2
}

National Cancer Institute

\section{Source}

National Cancer Institute. TGF-Beta Receptor Type-2. NCI Thesaurus. Code C17341.

T GF-beta receptor type-2 (567 aa, $\sim 65 \mathrm{kDa}$ ) is encoded by the human T GFBR2 gene.

This protein plays a role in both serine/threonine phosphorylation and T GF-beta-

mediated signal transduction. 